\title{
Ekspresi Bcl-2 dan Caspase-3 Pascapaparan Hipoksia Hipobarik Intermiten
}

\author{
Achmad Hidayat, ${ }^{1}$ Kahdar Wiradisastra, ${ }^{2}$ Bethy S. Hernowo, ${ }^{3}$ Tri Hanggono Achmad ${ }^{4}$ \\ ${ }^{1}$ Lembaga Kesehatan Penerbangan dan Ruang Angkasa Dr. Saryanto, ${ }^{2}$ Departemen Bedah Saraf, \\ ${ }^{3}$ Departemen Patologi Anatomi, ${ }^{4}$ Departemen Biokimia \\ Fakultas Kedokteran Universitas Padjadjaran-Rumah Sakit Dr. Hasan Sadikin Bandung
}

\begin{abstract}
Abstrak
Hipoksia hipobarik intermiten sering dialami oleh awak pesawat, karena selama di dalam kabin pesawat bernapas dengan tekanan udara yang lebih rendah. Tubuh akan beradaptasi dengan cara mengikat oksigen lebih banyak dan juga mengurangi dampak hipoksia. Fungsi mitokondria akan terganggu pada hipoksia, yaitu permiabilitas membran luar mitokondria karena protein Bcl-2 menurun. Jika hipoksia berlanjut akan terjadi kebocoran membran mitokondria, pelepasan sitokrom-c, dan proses apoptosis berlangsung. Penelitian ini bertujuan menganalisis protein Bcl-2 sebagai antiapoptosis dan caspase-3 sebagai indikator apoptosis akibat paparan hipoksia hipobarik intermiten. Dilakukan penelitian eksperimental pada tikus jantan Spraque Dawley periode Januari-April 2010 dengan melakukan paparan hipoksia hipobarik intermiten satu sampai empat kali dengan interval satu minggu. Jantung tikus dijadikan spesimen untuk dilakukan pemeriksaan ekspresi protein dengan pulasan imunohistokimia di Departemen Patologi Anatomi RS Dr. Hasan Sadikin Bandung dan western blot di Bagian Biomolekuler FK Universitas Indonesia Jakarta. Ekspresi protein Bcl-2 meningkat sesuai dengan frekuensi paparan hipoksia hipobarik intermiten, sebaliknya ekspresi protein caspase-3 menurun $(\mathrm{r}=-0,448, \mathrm{p}=0,013)$. Dari penelitian ini dapat disimpulkan bahwa terjadi penurunan tingkat apoptosis akibat paparan hipoksia hipobarik intermiten, hal ini disebabkan mekanisme adaptasi natural yang ditandai dengan menurunnya apoptosis sel dan secara tidak langsung akan memberi efek kardioprotektif. [MKB. 2011;43(4):166-70].
\end{abstract}

Kata kunci: Apoptosis, Bcl-2, caspase-3, hipoksia hipobarik intermiten

\section{Bcl-2 and Caspase-3 Expression Post Exposure of Intermittent Hypobaric Hypoxia}

\begin{abstract}
Intermittent hypobaric hypoxia often suffered by cabin crew due to the fact that they are breathing lower pressured air inside the plane cabin. Human body will adapt by binding more oxygen and reducing hypoxia effect. Mitochondria function will be irritated by hypoxia which affect, outer mithochondrial membrane permeability due to decrease of Bcl-2 protein. Later on if hypoxia continues mitochondrial membrane will leaked cytocrome-c will released and apoptotic pathway will occur. The purpose of this study was to analyze Bcl-2 protein as antiapoptosis and caspase-3 as apoptosis indicator of intermittent hypobaric hypoxia exposure. Experimental study was subjected to Spraque Dawley male mice during January-April 2010 by exposing them to several intermittent hypobaric hypoxias (one to four treatment) in an interval of one week. Protein expression on mice heart cell were detected by immunohistochemistry in the Department of Pathology Anatomy Padjadjaran University-RS Dr. Hasan Sadikin Bandung and western blot methods in Department Biomolecullar Indonesia University Jakarta. $\mathrm{Bcl}-2$ protein expressions increased according with the frequency of intermittent hypobaric hypoxia exposures, while a reverse trend was found for caspase- 3 protein expressions $\left(r_{s}=-0.448, p=0.013\right)$. From the study it can be concluded that apoptosis will be decreased as a result of intermittent hypobaric hypoxia exposures, which occurred from natural adaptation mechanism indicated by decrease of cell apoptosis and cardio protective effect will be emerged. [MKB. 2011;43(4):166-70].
\end{abstract}

Key words: Apoptosis, Bcl-2, caspase-3, intermittent hypobaric hypoxia

Korespondensi: Achmad Hidayat, dr., Sp.B., Sp.KP., MARS, Lembaga Kesehatan Penerbangan dan Ruang Angkasa Dr. Saryanto (Lakespra Saryanto), jalan MT Haryono Ka 26 Jakarta Selatan, telepon (021) 7996634, mobile 081310797959, e-mail hidayat_achmad@yahoo.com 


\section{Pendahuluan}

Hipoksia hipobarik intermiten sering dialami oleh para penerbang maupun awak pesawat lainnya, mereka akan bernapas dengan tekanan oksigen yang relatif rendah selama penerbangan. Pada ketinggian jelajah sekitar 30.000 kaki, tekanan udara di dalam kabin pesawat disesuaikan dengan ketinggian 6.000-8.000 kaki, berarti tekanan udaranya 560-590 mmHg. ${ }^{1,2}$ Tubuh manusia akan beradaptasi terhadap kekurangan oksigen tersebut, sehingga tidak terjadi gangguan fisiologis dan hal ini dikenal sebagai hypoxia preconditioning. ${ }^{3}$

Upaya yang dilakukan antara lain dengan mengikat oksigen secara kimia oleh protein hemoglobin, mioglobin, neuroglobin dan sitoglobin, serta mengurangi daya rusak sekecil-kecilnya. Protein yang mengatur dan sangat peka terhadap hipoksia adalah hypoxia inducible factor-1alpha (HIF-1 $\alpha)$ dikenal sebagai master switch gene, selanjutnya HIF-1 $\alpha$ akan mengendalikan ratusan gen lain seperti adenovirus E1B 19kDa interacting protein 3 (BNIP3), Glucose transporter 1 (Glut1), vascular endothelial growth factor (VGEF), abnormal erythropoietin (EPO), dan sebagainya. ${ }^{4}$

Keadaan tersebut terjadi di mitokondria dan salah satu reaksi terhadap hipoksia berupa menurunnya protein $\mathrm{Bcl}-2$ sebagai protein yang mempertahankan permiabilitas membran luar mitokondria. Jika hipoksia berlanjut, maka akan terjadi kebocoran membran dan sitokrom-c masuk ke dalam sitosol. Proses berikutnya akan terjadi apoptosis yang ditandai dengan peningkatan protein caspase-3.,6 Jalur apoptosis pada hipoksia akut sudah lama dikenal, akan tetapi bagaimana jika terjadi hipoksia intermiten, belum banyak dilakukan penelitian dan publikasi. Tujuan penelitian ini untuk menganalisis efek paparan hipoksia hipobarik intermiten terhadap jantung dengan mengukur ekspresi protein $\mathrm{Bcl}-2$ dan caspase-3.

\section{Metode}

Dilakukan penelitian eksperimental selama periode Januari-April 2010. Prosedur hipoksia hipobarik pada hewan coba sudah mendapat persetujuan dari Komite Etik Penelitian Kedokteran FK Unpad. Hewan coba dibagi dalam 5 kelompok (4 kelompok percobaan dan 1 kelompok kontrol), masing-masing kelompok terdiri atas 7 tikus jenis Spraque Dawley jantan dengan bobot 150-200 g. Kelompok 1 dilakukan satu kali paparan hipoksia hipobarik, kelompok 2 dua kali paparan, kelompok 3 tiga kali paparan, dan kelompok 4 dilakukan 4 kali paparan dengan interval 1 minggu. Alat yang dipergunakan hypobaric chamber ETC di Lakespra Saryanto milik TNI Angkatan Udara.
Perlakuan paparan hipoksia menggunakan type I chamber flight profile dengan modifikasi. Tikus dimasukkan ke dalam hypobaric chamber, kemudian dinaikkan ke ketinggian 35.000 kaki selama 1-2 menit, diturunkan pada ketinggian 25.000 kaki selama 5 menit, dan selanjutnya diturunkan ke ketinggian 18.000 kaki selama 25 menit. $^{7}$

Dalam keadaan hipoksia, tikus dianastesi umum dengan ketamin intramuskular, dan selanjutnya jantung tikus dikeluarkan. Sediaan dibagi dua bagian, bagian pertama dibuat blok parafin untuk pulasan imunohistokimia dan bagian lain diekstraksi protein dengan tripure isolation reagent untuk analisis western blot.

Pemeriksaan imunohistokimia dilakukan di Bagian Patologi Anatomi FK Unpad/RS Dr. Hasan Sadikin Bandung. Reagen yang dipergunakan antibodi primer: rabbit polyclonal to $\mathrm{Bcl}-2$ $\left(\right.$ Abcam $^{\mathrm{R}}$ Katalog ab7973) dan rabit polyclonal to caspase-3 Abcam $^{\mathrm{R}}$ katalog ab59388). Antibodi sekunder dengan biotinylated universal. Interpretasi dengan memberi skoring berdasarkan intensitas dan distribusi warna pada setiap slide sediaan. ${ }^{8}$

Pemeriksaan protein dengan western blot dilakukan di bagian Biomolekuler FKUI Jakarta. Reagen yang dipergunakan yaitu antibodi primer: rabbit polyclonal to Bcl-2 (Abcam $^{\mathrm{R}}$ Katalog ab7973), rabit polyclonal to caspase-3 (Abcam ${ }^{\mathrm{R}}$ katalog ab59388), antibodi sekunder: goat polyclonal to rabbit $\operatorname{IgG}-H \& L\left(\mathrm{Abcam}^{\mathrm{R}}\right.$ katalog ab6721). Interpretasi dengan menggunakan program adobe photoshop merekam pita protein yang terdapat dalam gel.

Analisis statistik menggunakan rumus korelasi rank Spearman $r_{s}$ dengan program SPSS versi 13. Penelitian ini mendapat persetujuan dari Komite Etik Penelitian Kesehatan Fakultas Kedokteran Universitas Padjadjaran-RS Dr. Hasan Sadikin Bandung.

\section{Hasil}

Pemulasan imunohistokimia dilakukan dengan antibodi spesifik, hanya 31 dari 35 slide yang dapat diinterpretasi ekspresi protein $\mathrm{Bcl}-2$ dan caspase-3. Tiap slide diberi skoring nilai rata-rata dari tiga lokasi berdasarkan intensitas (kuat/nilai 3, sedang/nilai 2, lemah/nilai 1, negatif/nilai 0) dan distribusi ( $>80 \%$ nilai $4,50-80 \%$ nilai $3,20-50 \%$ nilai $2,<20 \%$ nilai 1$)$. Skoring berkisar antara 1 sampai 7. Hasil pewarnaan imunohistokimia pada 2 macam protein, yaitu $\mathrm{Bcl}-2$ dan caspase-3 memberi warna sama dengan gradasi warna coklat terang, sedang, kurang, dan tidak coklat.

Untuk pemeriksaan ekspresi protein dengan western blot semua jaringan jantung dapat 


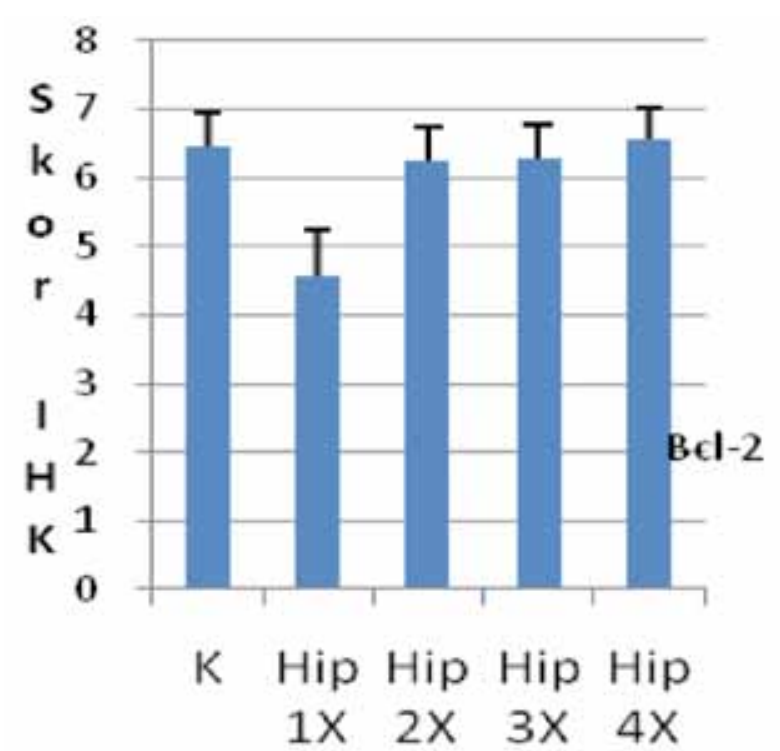

Kelompok paparan hipoksia

A

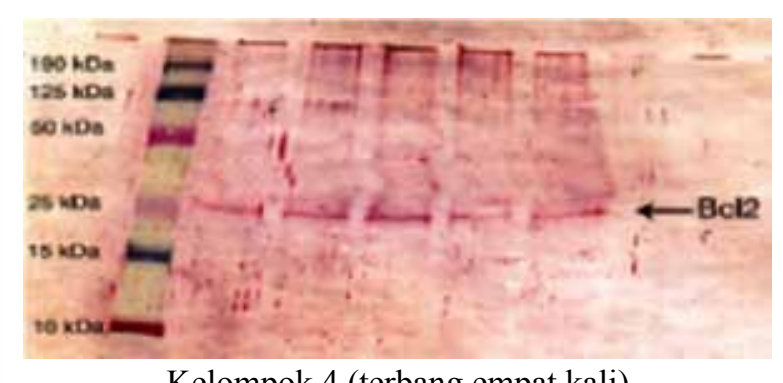

Kelompok 4 (terbang empat kali)

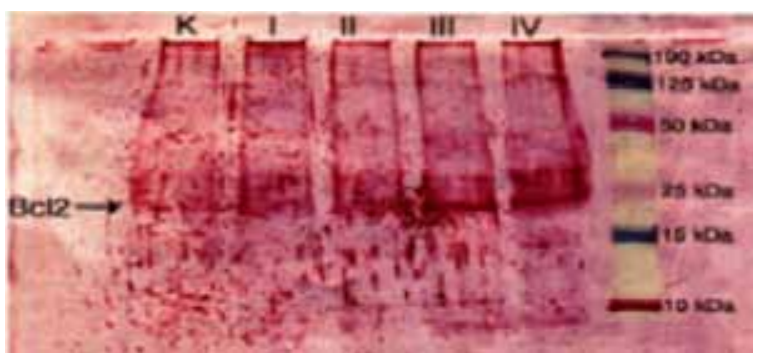

K: Kontrol

I: Terbang satu kali, II: Terbang satu kali, III: Terbang satu kali, IV: Terbang satu kali

\section{B}

Gambar 1 Ekspresi Protein Bcl-2 dengan Pulasan Imunohistokimia dan Western Blot Keterangan: A Skoring imunohistokimia kelompok perlakuan dan kontrol

B Pita Bcl-2 dengan western blot 4 kelompok perlakuan dan kontrol

diekstraksi proteinnya, kemudian masing-masing diperiksa protein Bcl-2 dan caspase-3. Ekspresi protein diamati sebagai pita dengan kilodalton yang spesifik, untuk mempermudah analisis dengan program adobe photoshop dikonversi dalam angka yang besarnya bergantung pada tebal tipisnya ekspresi protein tersebut.

Ekspresi protein $\mathrm{Bcl}-2$ dengan pulasan imunohistokimia pada 31 sampel diberi skoring pada berbagai tingkat hipoksia dan kontrol, selanjutnya dihitung nilai rata-rata dan simpangan baku tiap kelompok. Terlihat ekspresi protein Bcl2 tersebut cenderung meningkat sejalan dengan makin seringnya terpapar hipoksia hipobarik $(\mathrm{p}<0,05)$ (Gambar 1A). Demikian pula ekspresi protein Bcl-2 dengan western blot, pita pada elektroforesis terlihat semakin tebal sejalan dengan frekuensi hipoksia hipobarik intermiten (Gambar
1B).

Ekspresi protein caspase-3 dengan pulasan imunohistokimia pada 31 sampel diberi skoring pada berbagai tingkat hipoksia dan kontrol, selanjutnya tiap kelompok dihitung nilai ratarata dan simpangan bakunya. Terlihat ekspresi protein caspase-3 tersebut cenderung menurun sejalan dengan makin seringnya terpapar hipoksia hipobarik $(\mathrm{p}<0,05)($ Gambar 2A). Demikian pula ekspresi protein caspase-3 dengan western blot, pita pada elektroforesis terlihat semakin tipis sejalan dengan frekuensi hipoksia hipobarik intermiten (Gambar 2B).

Bila skoring imunohistokimia Bcl-2 digabung dengan caspase-3, maka semakin naik ekspresi Bcl2, akan terjadi penurunan ekspresi protein caspase-3 $\left(r_{\mathrm{s}}=-0,448 ; \mathrm{p}=0,013\right)$ (Tabel).

Tabel Ekspresi Protein Bcl-2 dan Caspase-3 Rata-rata dengan Skoring Imunohistokimia

\begin{tabular}{lccccc}
\hline Kelompok & Kontrol & 1x Hipoksia & 2x Hipoksia & 3x Hipoksia & 4x Hipoksia \\
\hline Bcl-2 & $6,44^{ \pm} 0,51$ & $4,59^{ \pm} 0,68^{* \Delta}$ & $6,23^{ \pm} 0,50^{*}$ & $6,27^{ \pm} 0,49^{*}$ & $6,54^{ \pm} 0,46^{* \Delta}$ \\
Caspase-3 & $2,11^{ \pm} 0,19$ & $5,09^{ \pm} 0,92^{* \Delta}$ & $4,43^{ \pm} 0,80^{*}$ & $3,77^{ \pm} 1,00^{*}$ & $2,95^{ \pm} 0,49^{* \Delta}$ \\
\hline
\end{tabular}

Keterangan: *perbedaan bermakna dibandingkan dengan kontrol $(\mathrm{p}<0,05)$

${ }_{\Delta}$ perbedaan bermakna antara kelompok hipoksia hipobarik $1 \mathrm{x}$ dan $4 \mathrm{x}(\mathrm{p}<0,05)$

Korelasi rank Spearman antara protein Bcl-2 dan caspase-3, $r=-0,448 ; p=0,013$ 


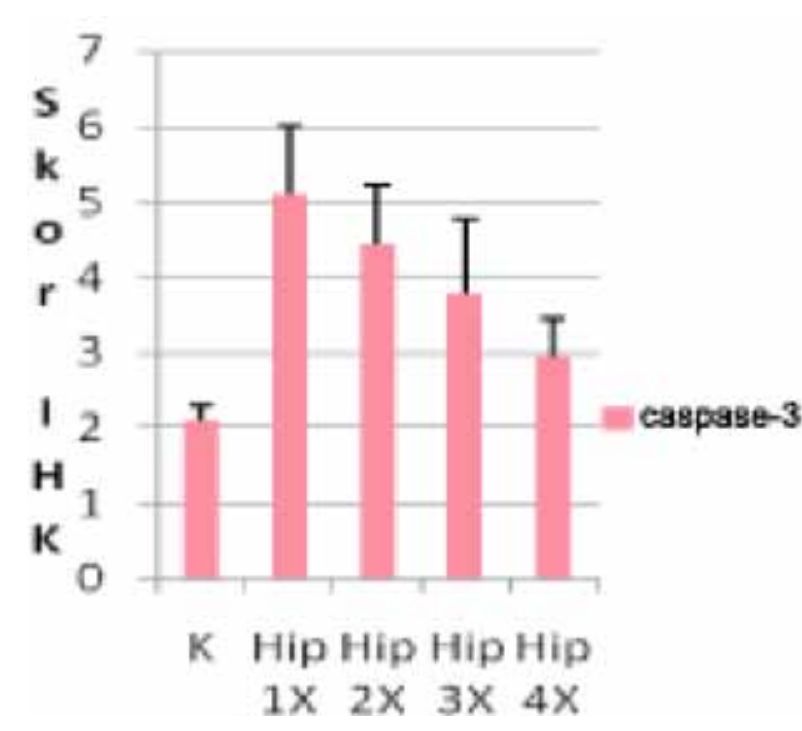

A

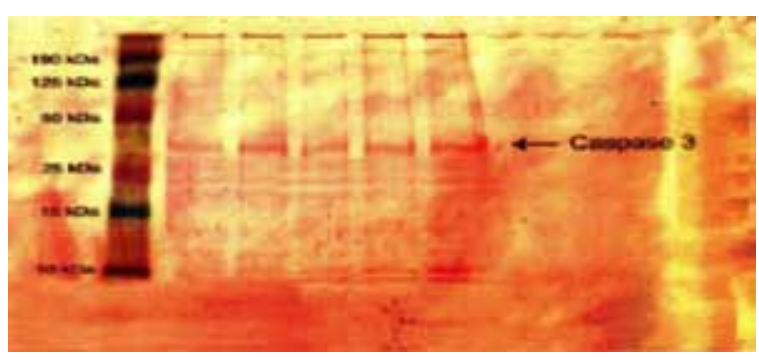

Kelompok 4 (terbang empat kali)

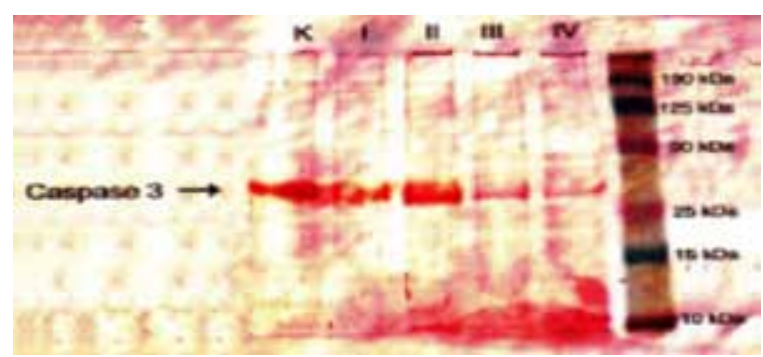

K: Kontrol

I: Terbang satu kali, II: Terbang satu kali,

III: Terbang satu kali, IV: Terbang satu kali

B

Gambar 2 Ekspresi Protein Caspase-3 dengan Pulasan Imunohistokimia dan Western Blot

Keterangan: A Skoring imunohistokimia kelompok perlakuan dan kontrol

B Pita caspase-3 dengan western blot kelompok perlakuan dan kontrol

\section{Pembahasan}

Ekspresi protein $\mathrm{Bcl}-2$ cenderung meningkat dengan makin seringnya terpapar hipoksia hipobarik (Gambar 1). Hal ini dapat dijelaskan sebagai berikut, mitokondria telah lama dikenal sebagai tempat transpor elektron dan pembangkit adenosin trifosfat (ATP), selain itu mitokondria juga diketahui sebagai tempat regulasi sel dalam hal survival. Dalam program apoptosis, mediator apoptosis dapat keluar dari mitokondria melalui celah membran luar (outer membrane mitochondria) yang rusak. Mediator ini kemudian berperan pada aktivasi caspase dan degradasi DNA. Peran regulator terhadap integritas membran luar mitokondria sangat penting dan Bcl-2 merupakan salah satu dari regulator tersebut. B-cell lymphoma 2 sebagai antiapoptosis telah diketahui dan beberapa peneliti mengetahui bahwa famili Bcl-2 mempunyai kemampuan membentuk pori. Kemampuan Bcl-2 membentuk jalur ke membran intrasel, juga berarti $\mathrm{Bcl}-2$ dapat mengendalikan permiabilitas membran luar mitokondria dan pada kondisi berikutnya mengatur homeostasis mitokondria. Beberapa peneliti telah mempublikasikan, bahwa permiabilitas mitokondria yang dijaga oleh protein $\mathrm{Bcl}-2$ akan terganggu pada keadaan hipoksia. Hal ini disebabkan karena Bcl-2 harus bersaing dengan Bak sebagai protein proapotosis, akibatnya terjadi ikatan $\mathrm{Bcl}-2$ dengan Bak, sehingga pori pada membran luar mitokondria akan terbuka dan keadaan ini dikenal sebagai mitochondrial apoptosis induced channel (MAC). Mitochondrial apoptosis induced channel tidak terjadi jika ekspresi Bcl-2 berlebih, sebaliknya jika Bcl-2 menurun akibat terikat Bak, maka MAC akan terjadi dan beberapa protein termasuk sitokrom-c akan keluar dan masuk ke dalam sitosol. Selanjutnya, melalui beberapa kaskade, maka akan masuk pada jalur apoptosis lewat caspase-3.9-11

Hipoksia Bcl-2 bukan satu-satunya faktor yang dapat menyebabkan terjadinya apoptosis, tetapi terdapat faktor lain seperti terganggunya pertukaran ion, transpor ATP, dan perbedaan voltage (the voltage dependent anion channel) yang memungkinkan transpor elektron berjalan baik. Keutuhan membran luar mitokondria dikendalikan oleh Bcl-2, maka peran Bcl-2 menjadi sangat dominan pada proses terjadinya apoptosis dalam kondisi hipoksia. Di samping itu, terdapat bukti-bukti bahwa perubahan metabolisme sel dapat mendorong terjadinya apoptosis, termasuk perubahan $\mathrm{pH}$, redoks potensial, dan transpor ion. Semua itu diregulasi oleh faal membran mitokondria dan di sini Bcl-2 berperan, sehingga permeabilitas membran mitokondria berfungsi dengan baik. ${ }^{12}$ 
Ekspresi protein caspase-3 cenderung menurun dengan makin seringnya terpapar hipoksia hipobarik, hal ini mungkin disebabkan juga karena pengaruh protein $\mathrm{Bcl}-2$ (Gambar 2). Dengan meningkatnya protein $\mathrm{Bcl}-2$, maka rasio BNIP3 lebih besar, akibatnya membran luar mitokondria tetap utuh dan kebocoran sitokrom-c dapat dicegah. Oleh karena sitokrom-c tidak keluar, maka faktor apoptosis tidak terinduksi dan caspase-3 akan menurun. Menurunnya ekspresi caspase-3 dapat merefleksikan penurunan apoptosis sel. ${ }^{13}$

Ekspresi protein $\mathrm{Bcl}-2$ meningkat seiring dengan makin seringnya paparan hipoksia hipobarik, sebaliknya ekspresi caspase-3 cenderung menurun, hal ini juga dipengaruhi oleh gen yang sangat sensitif terhadap hipoksia, yaitu $H I F-1 \alpha$ (Tabel 1). Ternyata pada keadaan hipoksia, gen $H I F-1 \alpha$ akan stabil dan tidak didegradasi. HIF$1 \alpha$ melalui hypoxia response element (HRE) akan menginduksi ratusan gen, termasuk di antaranya $B N I P 3 / B a k$ sebagai gen proapoptosis. Gen BNIP3 akan bersaing dengan $\mathrm{Bcl}-2$ yang bertugas menjaga permiabilitas membran mitokondria, karena rasio $B N I P 3$ terhadap Bcl-2 lebih besar, maka terjadi pori di membran, selanjutnya akan keluar sitokrom-c dan masuk dalam kaskade caspase. Pada keadaan hipoksia hipobarik intermiten ekspresi $H I F-1 \alpha$ dapat stabil dan terdegradasi secara teratur. Keadaan ini juga mempengaruhi ekspresi $B N I P 3$ dan Bcl-2 yang akan berubah-ubah sesuai dengan hipoksia intermiten tersebut, juga ekspresi caspase-3..$^{14-16}$

Simpulan, terjadi penurunan tingkat apoptosis akibat paparan hipoksia hipobarik intermiten, hal ini disebabkan mekanisme adaptasi natural yang ditandai dengan menurunnya apoptosis sel dan tidak langsung akan memberi efek kardiopropektif. Di masa datang perlu dicari formula hipoksia intermiten yang dapat dijadikan model untuk meningkatkan kebugaran serta proteksi pada organ yang padat mitokondria.

\section{Daftar Pustaka}

1. Hidayat A. Bunga rampai kedokteran penerbangan. Jakarta; 2001.

2. Hidayat A, Wiradisastra K, Hernowo BS, Hanggono T. Kardioproteksi akibat paparan hipoksia hipobarik intermiten. MKI. Inpress 2011.

3. Gustafson AB, Roberta G. Heart mitochondria: gates of life and death. Cardiovascular Research. 2008;77(2):33443.

4. Mohamad S. Alam terkembang jadi guru: kendali genetik terhadap cekaman oksidatif.
Orasi ilmiah pengukuhan sebagai guru besar ilmu kedokteran. Jakarta: Universitas Indonesia; 2008.

5. Graham RM, Frazier DP, Thomson JW, Haliko S, Li H, Wasserlauf B, dkk. An unique pathway of cardiac myocytes death caused by hypoxia acidosis. J Exp Biol. 2004;207:3189-200.

6. Lee S, Kuo W, Wu Y, Lin Y, Lin M, Lu A, dkk. Effects of short and long term hypobaric hypoxia on Bcl-2 in rat heart. Inter J Cardiol. 2003;103(3):376-84.

7. Tentara Nasional Indonesia. Markas Besar Angkatan Udara. Buku penunjuk tehnis TNI AU tentang indoktrinasi dan latihan aerofisiologis awak pesawat ABRI/TNI AU (Naskah sementara). Jakarta: 1998.

8. Hernowo BS. Laboratory manual. Workshop biologi molekuler, bioteknologi dan Imunohistokimia. Bandung: FK Unpad; 2009.

9. Eemenza GL, Shimoda LA, Prabhakar NR. Regulations of genes expression by HIF1 alpha, in Wiley, Chichester, signalling pathways in acute oxygen sensing. Novartis Foundation Symposium. 2005;272:2-14.

10. Burtscher M, Pachinger M, Ehrenbourg I, Mitterbauer G, Faulhaber M, Puhringer R dkk. Intermitten hypoxia increased exercise tolerance in elderly men with and without coronary artery disease. Int J Cardiol. 2004; 96(2):247-54

11. Yang J, Wang J, Zhu S, Chen X, Wu H, Yang D, dkk. C-reactive protein augments hypoxia induced apoptosis through mitochondriadependent pathway in cardiac myocytes. Mol Cell Biochem. 2008;310(1-2):215-26.

12. He A, Wang JA, Gui C, Jiang Y, Sun Y, Chen T. Change of mitochondrial pathway in hypoxia/reoxygenation induced cardiomyocytes apoptosis. Folia Histochem Cytobiol. 2007;45(4):397-400.

13. Chalah A, Khosrovi FR. The mitochondria death pathway. Adv Exp Med Biol. 2008; 615:25-45.

14. Jonas E. Molecular participation in mitochondrial cell death channel formation during neuronal ischemia. Exp Neurol J. 2009;218(2):203-12.

15. Bo H, Zhang Y, Ji LL. Redefining the role of mitochondria in exercise: a dynamic remodeling. Ann New York Acad Scienc. 2010;1201:121-8.

16. Kushnareva Y, Newmeyer DD. Bioenergetics and cell death. Ann New York Acad Scienc. 2010;1201:50-7. 